\title{
Influence of Financial Management Skills on Performance of Youth Environmental Projects: A Case of Solid Waste Management Projects in Nairobi County, Kenya
}

\author{
Nderitu B. Wanjiru, \\ School of Business, Monitoring and Evaluation, \\ Africa Nazarene University, Kenya \\ Prof. Dorothy Ndunge Kyalo, \\ Dr. Angeline Sabina Mulwa, \\ Dr. John Mbugua, \\ School of Open and Distance e-Learning, \\ University of Nairobi, Kenya
}

URL:http://dx.doi.org/10.19044/esj.2020.v16n7p50

\begin{abstract}
With the upsurge of unemployment, more youths are conducting garbage collection activities as an enterprise to improve their livelihood. This study examined the influence of financial management skills on performance of youth environmental projects in Nairobi County, a case of solid waste management projects. It was guided by pragmatism research paradigm adopting descriptive survey and correlational research designs. The study's target population was 700 youth group members engaged in solid waste management projects in Nairobi County, using a sample size of 248 group members, based on Krejcie and Morgan's sampling table. Key informants from 4 departments of Directorate of Youth affairs were purposely selected. Research instruments entailed questionnaires and interview guide. Qualitative data was analyzed and presented in narrative statements while inferential statistics were analyzed using Pearson correlation coefficient and multiple regression analysis to test hypotheses. The correlation index between financial skills and performance of youth environmental projects was positive and significant, $\mathrm{r}(247)=.525 ; \mathrm{p} \leq .05$. This inferred that as the level of financial project management skill increases, the performance levels also increase. The $\mathrm{T}$ value for financial management skills was also significant; $\mathrm{T}(247)=9.682$; $\beta=0.724$.; $\mathrm{P} \leq .05$. This implied that for each unit increase in financial management skills, the performance of youth environmental projects could increase by 0.724 units. This inferred the rejection of null hypothesis and the
\end{abstract}


conclusion made that $\mathrm{H}_{1}$ (There is a significant influence of financial management skills on performance of youth environmental projects in Nairobi County). The researcher recommends the pulling together of a common funding accessible to all youths by the government of Kenya and a policy action by the government to incorporate youths to learn financial management skills under mentorship programs from entities dealing with environmental projects so as to incubate their skills for effective project performance.

Keywords: Solid waste management, financial management skills, performance of youth environmental projects

\section{Introduction}

The rapid urban population upsurge in emerging third world countries has resulted in huge unplanned settlements with excessive amount of solid waste (World Vision Report, 2015). Research by Gakungu (2012) on solid waste management in urban areas reviews that urban areas create about 1.3 billion tons of strong waste every year, a volume expected to ascend to 2.2 billion tons by 2025. This is an additional twofold increment for creating nations (Gakungu et al., 2012). Industrial solid waste, household solid waste, hazardous waste, and agricultural waste are the major types of solid waste (ICA, 2010). Kenya's 2010 Constitution (Article 42) concerning the environment, provides that "every person has a right to a clean and healthy environment". However, lack of ability to provide infrastructural services to match rapidly growing population, including high commercial and industrial demands by the Nairobi City Council (NCC), has led to problems such as overcrowding of heaps of disposable waste, poor and inadequate sanitation, polluted water, poor health as a result of respiratory and waterborne diseases especially within the slums and the peripherals of dumpsites like Dandora (Nairobi dumping site), inadequate liquid and solid waste management, and lack of decent recreational facilities besides many other fashioned urban degeneration problems. The situation has subsequently led to amplified crime, mushrooming and encroaching of slums, construction of illegal structures, and rapidly declining standards of living (NCC, 2010). Most towns in Kenya have inefficient solid waste management systems. According to a study completed by Habitat, the findings stated that 30-40 percent of waste generated in Nairobi is not collected and that only 50 percent of the population is served (NEMA, 2016). Waste collection charges in urban areas are higher than the ideal charges. Also, municipalities in charge of collection are not able to generate a good fee collection rate since residents do not get good services. This makes them always reluctant to pay, thereby exacerbating the vicious cycle of poor waste management save, in the residential areas (Frediani, Walker \& Butcher, 2013). 
Waste picking by waste pickers is relatively a phenomenon that is intense in urban areas. With slight or absolutely no capital being provided to the youths where the overall resources are scarce, waste picking becomes an important survivalist strategy for most unemployed youths. Solid waste management youth projects entails dealing gainfully with the increasing volumes of solid waste in Nairobi County with quite common mountains and heaps of refuse which harbor vectors of transmissible diseases including rodents and insects. This increases the potential for the spread of infectious diseases including malaria, tuberculosis, and diarrhea within the residential areas (Kajamaa, 2011). Solid waste transportation involves the collection of waste from residential homes, including transmission from designated stations where solid waste is temporally concentrated and refilled onto designed tracks for delivery to the landfill or disposal sites (Kajamaa, 2011).

Furthermore, keeping accurate records is one of the most vital financial practices needed for monetary enactment of a given project over time. Mathematical and scientific tasks like estimated requirements of a project record keeping typically used in many projects consist of books of accounts that comprise journals, ledgers, and other classified records of a project's set of accounts which is essentially financial management (Agwu, 2014). Using a template to create a budget helps project teams to be in control of finances more and also promote savings. Accounting involves bookkeeping for both revenues and expenditures at unit and project levels. Budgeting also offers an ongoing check for expenditure judgment by comparing actual outlays against projected incurred costs (Georgieva \& Allan, 2008). Financial management skills espoused in this study alludes to arrangement of files for the documents that need to store evidence on the project costs and benefits achieved. The documents include financial information as well as details of the project activity and its results. Youth financial management skills pertain to record keeping of all solid waste management project activities. This ranges from control of dumping places, collection of the solid waste, transportation to designated dumping sites, disposal of waste, and processing including recycling (Agwu, 2014).

In lieu of this, 70 youth environmental group projects out of 400 registered youth groups in Nairobi County pose as "waste pickers" in solid waste management projects for their livelihood. The environmental youth projects are hence expected to meet economic needs, fit within governmentfunded program objectives, and add value to the beneficiaries whilst providing employment or self-employment opportunities by opening up business ventures for the bulging youth population as exit opportunities from the program (UNEP, 2011).

However, there are scanty youth's business progress or discontinuance rates reported in these environmental projects with scanty indicators on 
performance (YEDF, 2016). The performance of many of the youth environmental projects in all the 47 counties in Kenya remains thin, irrespective of government funding. Therefore, there is a need to save Nairobi County which has more youths accessing government projects funding and training heightened by proximity (Afon, 2012). A significant share of the reported failed projects is termed to be government funded and donor funded where they usually undergo the required financial management process which are often legal donor requirement. Literature reviews show that youths lack project management financial skills and self-confidence. This may have a significant impact on their creativity and innovative ability to take calculated risks and to use available opportunities as well as available business government support for gainful project startups and growth (Kenya Economic Survey, 2015). This study therefore seeks to investigate the missing links leading to poor performance of youth groups' solid waste management projects by investigating how financial management skills influence performance of youth environmental projects.

\section{Objective of the Study}

The study was guided by the following objective: To assess the extent to which financial management skills influence performance of youth environmental projects in Nairobi County, Kenya.

\section{Research Question}

The study sought and answered the following research question: How does financial management skills influence performance of youth environmental projects in Nairobi County, Kenya?

\section{Research Hypothesis}

The study tested the following research hypothesis:

$\mathrm{HO}$ : There is no significant relationship between financial management skills and performance of youth environmental projects in Nairobi County, Kenya.

\section{Literature Review}

Financial management skills in this context entails the managerial and regulatory knowhow ranging from registration of business, duration taken to register, a likely responsibility for handling multimillion-pound budgets, procedures, capital requirements, including property rights (Financial Knowledge and Behavior Survey, 2013). A descriptive research was conducted by Adomako Ramesh, Natraj, and Ponna (2014) targeting school youths who owned small ventures on business analytics aimed at teaching introduction to business financial management skills and business analytics in the context of both current and prospective business. The study conclusion 
agreed with the facts that financial management skills entail key monetary literacy and appreciation of procedures such as budgeting, reporting, and forecasting. This provides a clear understanding of how a project runs and makes money, which is a major key to growing businesses and developing record keeping. This attributes to an economic value in a project business by managing financial performance indicators linked to profit goals set, products sales, and market efficacy. Project teams with financial management acumen are unlikely to hold inadequate cash, apply debt more attentively, and are more sophisticated in using suitable discount rates when appraising projects. They are also extra effective at communicating with clients and more popular at obtaining access to outside financing when facing limited credit supply (Custódio, Mendes \& Metzger, 2016). Financial management skills include money-saving habits with a realistic savings plan. Youth groups should document projects' novel entries of monetary properties into designated journals and accounts, with suitable references to the underpinning documents (Adomako et al., 2014). With official groups, reputable chart of accounts is used in recording transactions. Using simple document(s) for every itemized transaction, the bookkeeper registers original entries into the journal then to the business's accounts. Journal entry document entails the whole youth group solid waste management project transaction being captured in one place (Davis \& Kate, 2014). They generally contain account records with specific information like accounts receivable and payable, payroll data, and financial information concerning project jobs proceeding within the billing process (Michael, 2016).

Prioritizing goals in a given project may give a clear idea of where to start saving. A study by Rebecca (2016) on saving habits shows that certain investors put their money in a jar, coffee cans or a form of piggy bank (Rebecca, 2016). For short spells of time and for small amounts of money, the piggy bank method may work. However, long-term savings requires a safer method. Her study recommends saving money at a depository institution that gives ideal financial services to youths, such as savings and checking accounts. Unlike tangible money deposited at home which is prone to fire, burglary or some other types of risks or disaster, money saved at a depository institution is constantly protected from fitful loss (Rebecca, 2016). Study on savings by Boateng, Samuel, Baidoo, and Amponsah (2018) on the role of financial literacy in savings decisions was conducted in Ghana. The researchers used primary data, which was analyzed using a regression model. The study findings, which employed estimation technique, indicated that improving financial literacy portrayed that depository organizations propose accounts that earn interest. Thus, this allows customers or youths to benefit from the time value of money. Almost all banks offer automated transfers between checking and savings accounts, which is an ideal way to save money. 
However, money market deposit accounts generally require ample cash to open and often have limits on the number of times that money can be withdrawn from the account every month (Boateng et al., 2018).

The lending activity of banks on youth projects constrains youths' environmental activities since it becomes difficult to secure finances. Moreover, majority of Kenyan youth groups face several huddles in accessing government funding or loans for their environmental projects, thereby segregating a bigger proportion of potential beneficiaries. For example, some youths face difficulties to fulfill YEDF requirements such as generating a viable business plan, being in a legitimate registered group, and having a prevailing bank account which is the requirement for accountability during loan repayment. As a result of this, budgeting projects daily which is a mundane activity may pose a challenge. A study that was conducted by researchers, Oduol, Okoth, Okelo, Aila, Abiud, Awiti, Maria, Ogutu, and Odhiambo (2016), on the effect of the Youth Enterprise Development Fund (YEDF) on youth enterprises in Siaya County, Kenya, used stratified random sampling on 28 selected financiers of YEDF. This was carried out on a target population of 202,897 youths in the county and a sample size of 128 respondents. Here, 28 respondents were in the first stratum while 100 respondents were in the second stratum. The data collection instruments included survey questionnaires which were analyzed using multiple linear regression analysis. The study findings concluded that the YEDF did not have a significant effect on youth enterprises. Therefore, proliferation of financial intermediaries (FIs) was recommended in partnership with the fund with vigorous participation of all the stakeholders towards mobilization of the youth on enterprise project groups' improvement and YEDF activities (Oduor et al., 2013). The study alluded to changes in government and policy regulatory reforms affecting youth support budget packages and representation. The financial aspects of solid waste management concerns budgeting and cost accounting, capital investment, cost recovery, and cost reduction. Major preferences for financing capital investment for solid waste management especially on youth projects entail homegrown budget sourced resources, available loans from financial intermediaries, and distinct government youth loans or grants (Rebecca, 2016).

\section{Theoretical Framework}

This study is linked to theoretical underpinnings that relate to human capital theory by Becker (1964) with a concept of performance empirically. The theory assumes the diversity of views, value systems, and needs that are acknowledged and utilized in the study of environmental projects towards the delineation of innovative solutions. Human capital is a term that describes hierarchy of skills and knowledge. It is also one of the most used theories in 
relation to project readiness and ability (Wright $\&$ McMahan, 1992) with a set of skills and characteristics that may increase productivity, indicating significant relationship between innovativeness and project performance. Human capital theory in relation to project innovative skills include financial performance measures such as projected percentage of sales resulting from new products, amount of capital employed, rate of profitability, return on investment (ROI) rate, including return on assets (ROA) rate (Gratton \& Ghoshal, 2003). The assumption of human capital theory and performance is based on the link between resource-based view of the project and the expectancy theory of motivation. This is composed of the valence or value attached to rewards, the instrumentality or the belief that the project team receives a reward upon reaching a certain level of performance (Vroom, 1964). Based on the views of Gratton and Ghoshal (2003), human capital theory assumes that engaging youth in financial management skills contributes to higher knowledge and skills that will boost their future enterprise with increased productivity and higher owner wages. The propositions of this theory embrace learning that is learner-centered, whereby knowledge is created through experiential learning.

The expectancy theory of motivation states that the intensity of a tendency to perform in a particular manner is dependent on the intensity of an expectation that the performance will be followed by a definite outcome. The theory assumes that youth and environmental projects stewardship actions contribute towards natural capital (biodiversity and ecosystems), which in turn produces ecosystem services and participation in civic ecology activities. Consequently, this enhances the links, shared values, and understandings among the youth groups. This enables them to work together-social capital (UNESCO, 2013) - in respect to solid waste management projects. These theories fulfill the gap in knowledge in this study since they are pragmatic at micro levels. They offer the rationale behind knowledge and skills that increase youth entrepreneurial prospects in generation of income, and this helps solid waste management projects funded by the government.

\section{Conceptual Framework}

This study was guided by the following conceptual framework that shows diagrammatized representation of the relationship between the variables. This is shown in Figure 1. 


\section{(Moderating variable)}

Figure 1. Conceptual framework for financial management skills and performance of youth environmental projects:

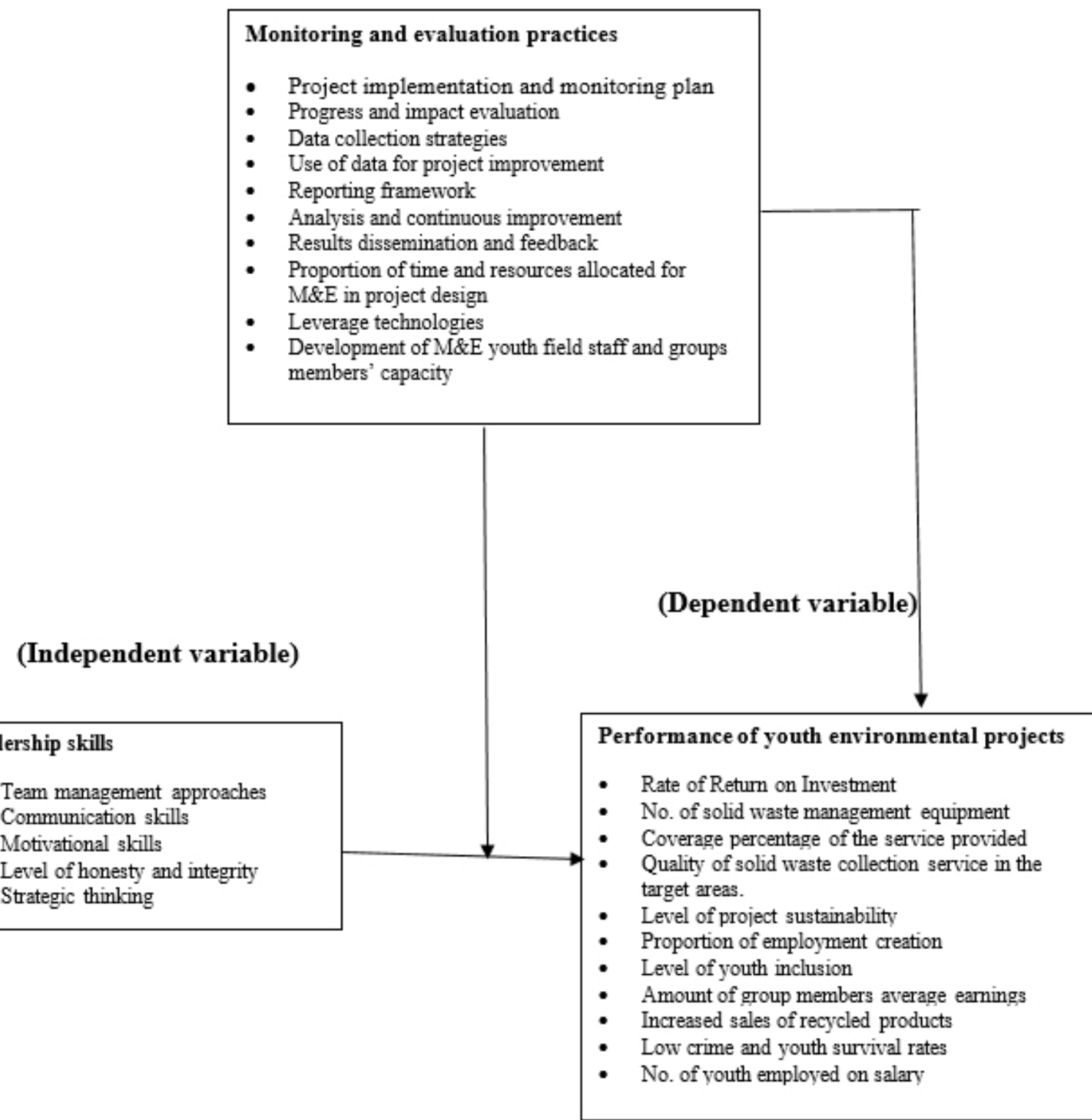

(source: Author)

\section{Research Methodology}

\section{Research paradigm and design}

This study was guided by positivists and naturalist (constructivist) forms of inquiry referred to as the pragmatism paradigm. This was grounded on the notion that mixed methods explore a concept from more than one 
methodological perspective. Thus, this makes it more 'practical' in terms of overall outcomes (Lincoln \& Guba, 1985). The study applied descriptive research and exploratory research designs. The research was preplanned and structured in design so that the information collected could be statistically inferred on the respondents since descriptive design is conclusive and quantitative in nature.

\section{Study Population}

The study population was 700 youth groups beneficiaries' who included the urban youths in Nairobi County engaged in government funded solid waste management projects, drawn from the seventeen sub counties in Nairobi County.

\section{Sample size}

The sample size of 248 youths was obtained using the Krejcie and Morgan table (1970). This was a representative size for a target population of 700. The sample size table was calculated using proportionate Yamane method; $(\mathrm{x} / 700 * 248)$; while the actual respondents from the number of youth members per group was homogenously selected using simple random sampling. The sample size was then studied and inference made to the larger population.

\section{Data Collection and administration}

Data was collected using questionnaire guide and an interview guide. The concept of this research instrument was derived from objectives of the study which were operational form of theoretical construct of phenomenon under inquiry. The questionnaire guide was a list of standard questions to gather both qualitative and quantitative information from the scope of study using both open and close - ended questions. Open ended questions enabled the respondents to complete the questionnaire in their own views. Data was administered through Nairobi Sub County Officers in charge of the Youth environmental groups in Nairobi County using a list of youths from the sampled groups. Data collection process was expedited by calling group sites meetings with the respondents that enabled the researcher to administer the questionnaire through face to face interaction during the site visits. The researcher also conducted in-depth interviews to garner empirical data from the respondents who were the heads of departments in the Directorate of Youth.

\section{Validity and reliability of the Instrument}

The researcher validated the research instruments through the assessment of validity which was subjected to a judgmental approach by the 
researcher's peers as recommended by Rist, 2012, for evaluation to ensure that it included all the items that were necessary and eliminating detrimental items to a particular construct domain. To test reliability, 10 percent (Patton, 2008), twenty (25) respondents from the sample size were administered to the questionnaire. They were not involved in the actual research groups and they were excluded from final analysis. The researcher determined the internal consistency of Likert scale items using Cronbach's Alpha (Lee Cronbach's in 1951) at a score of between zero and one, with 0.7 generally accepted as a sign of acceptable reliability.

\section{Data presentation Method}

Data was presented by use of figures and tables which was a clear representation of the Influence of Financial Management Skills on Performance of Youth Environmental Projects: A Case of Solid Waste Management Projects in Nairobi County, Kenya.

\section{Data analysis}

Preliminary data was edited, coded, cleansed and rechecked to minimize data entry errors. Qualitative data was analyzed and presented verbally based on themes, while quantitative data was analyzed descriptively using percentage frequencies, mean, and standard deviation. Inferentially, Pearson correlation coefficient and simple linear regression analysis was used to test hypotheses $\mathrm{P}=\beta 0+\beta_{1} \mathrm{FS}+\varepsilon$; and t-test was used as a tool of analysis to test for significance level at 0.05 on the null hypothesis.

\section{Results of the Study}

\section{Financial Management Skills and Performance of Youth Environmental} Projects

The objective of this study was to assess the extent to which financial management skills influence performance of youth environmental projects. To achieve this, the respondents were asked to give their opinions based on their level of agreements or disagreements with the statements based on a Likert scale of 1-5 where 1=strongly Disagree, 2=Disagree, 3=Neutral, 4=Agree, and 5=Strongly Agree. The results were presented in Table 1.1. 
Table 1.1 Financial Management skills and Performance of Youth Environmental Projects

\begin{tabular}{|c|c|c|c|c|c|c|c|}
\hline Statements & SD & $\bar{D}$ & $\mathrm{~N}$ & A & SA & Mean & $\begin{array}{c}\text { Std. } \\
\text { Deviation } \\
\end{array}$ \\
\hline $\begin{array}{l}\text { 1. All project procedures which are } \\
\text { captured in every fiscal budget of } \\
\text { the group budget depend on } \\
\text { available government financial } \\
\text { solutions }\end{array}$ & $89(35.9)$ & $159(64.1)$ & 0 & 0 & 0 & 1.64 & 0.481 \\
\hline $\begin{array}{l}\text { 2. We spend our group savings } \\
\text { when we run out of money before } \\
\text { the next government funding arrives }\end{array}$ & $20(8.1)$ & $9(3.6)$ & $18(7.3)$ & 191(77.0) & $10(4.0)$ & 3.65 & 0.931 \\
\hline $\begin{array}{l}\text { 3. Group members understand } \\
\text { parameters that determine services } \\
\text { offered by banks and other financial } \\
\text { intermediaries }\end{array}$ & $25(10.1)$ & $163(65.7)$ & $12(4.8)$ & $48(19.4)$ & 0 & 2.33 & 0.903 \\
\hline $\begin{array}{l}\text { 4. My group has a robust knowledge } \\
\text { management system for all entries } \\
\text { and expenditures }\end{array}$ & $14(4.6)$ & $206(83.1)$ & $6(2.4)$ & $22(8.9)$ & 0 & 2.15 & 0.645 \\
\hline $\begin{array}{l}\text { 5. Our financial statements, and } \\
\text { other aspects of youth project } \\
\text { activities, have been audited within } \\
\text { the last two years either by a } \\
\text { governmental agency or } \\
\text { independent public accountant }\end{array}$ & $24(9.7)$ & $153(61.7)$ & $60(24.2)$ & $11(4.4)$ & 0 & 2.23 & 0.681 \\
\hline $\begin{array}{l}\text { Composite mean and standard } \\
\text { deviation }\end{array}$ & & & & & & 2.40 & 0.399 \\
\hline
\end{tabular}

Table 1.1 presents the responses of financial management skills on performance of youth environmental projects in Nairobi County. The results were presented using mean and standard deviation. Five statements were developed to measure the extent to which financial management skills influence the performance of youth environmental projects.

Statement 1 "All project procedures captured in every fiscal budget of the group depend on available government financial solutions" results indicated that 159 respondents $(64.1 \%)$ disagreed with the statement while 89 respondents (35.9\%) strongly disagreed with the statement. This line item had a mean of 1.64 and a standard deviation of 0.481 which was lower than the composite mean of 2.40 and a standard deviation of 0.399 . This implies that all the 248 respondents disagreed with this statement, meaning that this statement negatively influences performance of youth environmental projects in Nairobi County. This finding agrees with the study of Rebecca (2016) who found out that savings habits and financial aids to people with lower income like youths can give them access to acquire financial management skills 
(Rebecca, 2016). Thus, this is especially when engaged in solid waste projects which may demand constant funding to upgrade waste disposal and recycling mechanisms.

Statement 2 "We spend our group savings when we run out of money before the next government funding arrives" results indicated that 191 respondents $(77.0 \%)$ agreed that they spend their group savings when they run out of money before the next government funding arrives, $10(4.0 \%)$ strongly agreed, $20(8.1 \%)$ strongly disagreed with the statement, $18(7.3 \%)$ were neutral, and $9(3.6 \%)$ disagreed with the statement. This had a line item mean score of 3.65 and a standard deviation of 0.931 which was much higher than the composite mean of 2.40 and a standard deviation of 0.399 , implying that this statement positively influences performance of youth environmental projects. However, the line item standard deviation was higher than the composite standard deviation implying there was a divergent opinion. This finding supports the exploratory study conducted by Adamako et al. (2014) on budgeting in project management who found that youth with limited knowledge on handling finance tend to hold wrong opinions and make incorrect financial management decisions.

For statement 3 "Group members understand parameters that determine services offered by banks and other financial intermediaries”, 163 respondents $(65.7 \%)$ disagreed that group members understand parameters that determine services offered by banks and other financial intermediaries, 25 respondents $(10.1 \%)$ strongly disagreed, 48 respondents $(19.4 \%)$ agreed with the statement, while $12(4.8 \%)$ were neutral. This line item had a mean score of 2.33 and a standard deviation of 0.903 which was lower than the composite mean of 2.40 and a standard deviation of 0.399 , implying that this statement negatively influences performance of youth environmental projects. The line item standard deviation was higher than the composite standard deviation meaning there was a divergence. This finding agrees with those of Adomako et al. (2014) on budgeting in project management and the impetus of financial management skills toward performance of youth projects.

Statement 4 "My group has a robust knowledge management system for all entries and expenditures" results indicated that 206 respondents $(83.1 \%)$ disagreed with the statement, 14 (4.6\%) strongly disagreed with the statement, 22 respondents $(8.9 \%)$ agreed, and the lowest response was 6 $(2.4 \%)$ who were neutral. This line item had a mean score of 2.15 and a standard deviation of 0.645 which was lower than the composite mean of 2.40 and a standard deviation of 0.399 , implying that this statement negatively influences performance of youth environmental projects. This finding agrees with a study by Boateng et al. (2018) which shows the benefits of book keeping and financial literacy for successful implementation of project management. 
Statement 5 "Our financial statements, and other aspects of youth project activities, have been audited within the last two years by either a governmental agency or independent public accountant" results indicated that 153 respondents $(61.7 \%)$ disagreed that their financial statements and other aspects of youth project activities have been audited within the last two years by either a governmental agency or independent public accountant, 24 respondents $(9.7 \%)$ strongly disagreed, 60 respondents $(24.2 \%)$ remained neutral, and 11 respondents $(4.4 \%)$ agreed. This line item had a mean score of 2.23 and a standard deviation of 0.681 which was lower than the composite mean of 2.40 and a standard deviation of 0.399 , implying that this statement negatively influences performance of youth environmental projects. This finding agrees with literature reviewed on this study on financial acumen in project management.

Key informants interviews were conducted from the sub-county youth monitoring and evaluation officers in the Directorate of Youth pertaining to the youth group's knowledge toward financial management skills and performance of youth environmental projects. Thus, they had this to say:

"Most groups do not comprehend what a fiscal budget is or available government financial solutions irrespective of sporadic trainings that they are given through the entrepreneurial training manual before the uptake of loans which entails basic book keeping and generation of a business plan. Most of the groups treasures are chosen by the group members due to their focal expression rather than what they can deliver. Group members assume that their savings is what the group uses to buy simple equipment's like wheelbarrows, gloves, blooms and aprons. However, some groups have bank accounts though with little understanding on bank operations and services. Other groups document their income and expenditures in minutes taken during their weekly, biweekly or monthly meetings".

When asked whether there is a framework to capture and record youth loan reimbursement process after uptake to mitigate against defaulters, and the challenges therein, this is what one of the youth officers had to say:

"Most of the youths in my region have defaulted Uwezo fund loans irrespective of the financial management training that we accord them before the uptake of loans that takes three to five days using the Uwezo fund entrepreneurial capacity building manual. This is because irrespective of meeting the loan disbursement criteria, they borrow the money with a perceived mind-set that they shall default. For example, I approved 14.6 
million shillings to different youths last fiscal year and I have only managed to recover 3.4 Million Kenya shillings. Meaning that I still have to follow up with dynamic youths to recover about 11 million Kenya shillings. Some of my youths after acquiring the loan decided to upgrade their mobile phones. Others colluded among the officials and eloped with the money. I reported the incidence to the Office so that an action can be taken against them".

Following the observation checklist, many respondent groups in this study apart from the city council groups never had their accounts audited. This implies that youths need formal training on financial management and budgeting skills. Majority of the groups were observed to rely on government funding while a few youth groups relied on politicians to partially fund some of their solid waste management activities. Most groups talked of aligning their activities with the vision 2030 but lacked any customized systems.

\section{Inferential Statistics of Financial Management Skills and Performance of Youth Environmental Projects}

Correlation and regression analysis were both conducted to determine the relationship between financial management skills and performance of youth environmental projects. These were further explained in the following sub-themes:

\section{Correlation of Financial Management Skills and Performance of Youth Environmental Projects}

Correlation analysis was conducted to establish the relationship between financial management and performance of youth environmental projects. The results were presented in:

Table 1.2. Correlation between Financial Management Skills and Performance of Youth Environmental Projects

\begin{tabular}{llcc}
\hline \multicolumn{2}{c}{ Variables } & Performance & Financial \\
\hline Performance of & Pearson Correlation & 1 & $0.525^{* *}$ \\
youth & Sig. (2-tailed) & & .000 \\
environmental & $\mathrm{n}$ & 248 & 248 \\
projects & Pearson Correlation & $0.525^{* *}$ & 1 \\
& Sig. (2-tailed) & 0.000 & \\
Financial & $\mathrm{n}$ & 248 & 248 \\
& $* *$ Correlation is significant at the 0.01 level (2-tailed)
\end{tabular}

The correlation output in Table 1.2 shows that financial management characteristics were statistically significant (P-values under significant 2tailed were all less than $\alpha=0.05$ ) toward performance of youth environmental 
projects. From Table 1.2, the correlation index between financial management and performance was positive and significant, $\mathrm{r}(247)=.525 ; \mathrm{p} \leq .05$. This implies that as the level of financial skills increases, the performance of youth environmental projects also increases.

\subsubsection{Regression Analysis of Financial Management Skills and Performance of Youth Environmental Projects}

Additionally, to estimate the overall effect of financial management skills on performance of the youth environmental projects, a regression analysis was run on the two variables and results were shown in Table 1.3. It can be noticed that the model summary Table 1.2 of regression, showed that the coefficient of correlation was 0.525 with an $\mathrm{R}$ square of 0.276 implying that the financial management skills variable can explain about 28 percent of the total variance in performance of youth environmental projects.

Table 1.3. Regression Analysis of Financial Management Skills and Performance of Youth

Environmental

Model Summary

\begin{tabular}{cccccccccc}
\hline Model & R & R & Adjusted & \multicolumn{3}{c}{ Std. Error } & \multicolumn{3}{c}{ Change Statistics } \\
Square & R Square & of the & R Square & F & df1 & df2 & Sig. F \\
Estimate & Change & Change & & & Change \\
\hline 1 & $0.525^{\mathrm{a}}$ & 0.276 & 0.273 & 0.46890 & 0.276 & 93.746 & 1 & 246 & 0.000 \\
\hline
\end{tabular}

As to whether this model was significant in enabling predictions containing the independent and dependent variable, the ANOVA table was produced and the results are as shown in Table 1.4.

Table 1.4. ANOVA Showing Regression Model for Financial Management and Performance of Youth Environmental Projects

\begin{tabular}{llcccccc}
\hline Model & Sum of Squares & Df & Mean & Square & F & Sig. & \\
\hline 1 & Regression & & 20.612 & 1 & 20.612 & 93.746 & $0.000 \mathrm{~b}$ \\
& Residual & 54.087 & 246 & 0.220 & & & \\
& Total & & 74.698 & 247 & & & \\
\hline
\end{tabular}

a. Dependent Variable: Performance

b. Predictors: (Constant), Financial

The ANOVA Table 1,4 shows that the global model containing the predictor of financial management and performance was significant; $F(1,246)$ $=93.75 ; \mathrm{P} \leq .05$. This implies that the regression coefficient of the predictor variable cannot be equal to zero, thus making the predictive power of financial management on performance to be high.

Lastly, it was important to establish the amount of contribution that financial management skills had on the outcome variable of performance. These results are presented in Table 1.5 on regression coefficient and was reported using the t-value statistics. 
Table 1.5. Regression Coefficients of Financial Management and Performance of Youth Environmental Projects

\begin{tabular}{lllllll}
\hline Model & Unstandardized & Coefficients & \multicolumn{2}{l}{ Standardized Coefficients } & T & Sig. \\
\hline \multirow{4}{*}{1} & & B & Std. Error & Beta & & \\
& (Constant) & 1.876 & 0.182 & & 10.302 & 0.000 \\
& Financial & 0.724 & 0.075 & 0.525 & 9.682 & 0.000 \\
\hline
\end{tabular}

Table 1.5 of regression coefficient shows the unstandardized beta coefficient for financial management skills to be 0.724 . The $\mathrm{T}$ value for financial management skills is also significant; $\mathrm{T}(247)=9.682 ; \beta=0.724$.; $\mathrm{P} \leq .05$. This implies that for each unit increase in financial management skills, the performance of youth environmental projects could increase by 0.724 units.

\section{Hypothesis Testing}

The study sought to examine the financial management skills and the performance of youth environmental projects. Pearson correlation coefficient was used to test the relationship between financial management skills and performance of youth environmental projects. This was done at $95 \%$ level of confidence to test the extent of the relationship between financial management skills and performance of youth environmental projects. The hypothesis was tested at 0.05 level of significance which stated that $\left(\mathrm{H}_{0}\right)$ : There is no significant relationship between financial management skills and performance of youth environmental projects in Nairobi County. From the findings of correlation and regression analysis, the correlation index between financial management skills and performance was positive and significant, $r$ (247) $=.525 ; \mathrm{p} \leq .05$. Implying that as the level of financial skills increases, the performance of youth environmental projects also increases. Regression coefficient shows the unstandardized beta coefficient for financial management skills at $\mathrm{T}(247)=9.682 ; \beta=0.724 ; \mathrm{P} \leq .05$, implying that for each unit increase in financial management skills, the performance of youth environmental projects could increase by 0.724 units. This depicted that financial management skills significantly influence the level of performance of youth environmental project which therefore led to the rejection of the null hypothesis which stated that:

$\mathrm{H} 0$ : There is no significant relationship between financial management skills and performance of youth environmental projects in Nairobi County and accepting alternative hypothesis that:

H1: There is a significant relationship of financial management skills on performance of youth environmental projects in Nairobi County, which was the alternative hypothesis. 


\section{Conclusion}

The objective in this study was to assess the extent to which financial management skills influenced the performance of youth environmental projects. Following statistical analysis, the study concluded that there is a significant relationship between financial management skills and performance of youth environmental projects in Nairobi County.

\section{Recommendations}

Based on this finding, the following suggestions were recommended:

i. Provision of more robust project financial management skills training paradigm and exposure that are not marooned by available government financial solutions linked to the traditional Entrepreneurial Training Manual only since most youths have basic financial knowledge with no skills at face validity. This would expose the youths to gainful financial skills and parameters that would boost the performance of government-funded youth environmental projects.

ii. Policy actions by the government to incorporate youths to learn project management skills. This specifically includes the financial aspect under mentorship programs from corporations, firms, and other public entities so as to incubate their skills for effective projects performance.

iii. Provision of easy-to-understand accounts that are easily accessible is also highly recommended. This can be achieved by encouraging youths with very lowest incomes to open an account with simplicity for savings and bonus payments to give them greater effects with interests due to complexity of financial products generally. This is in combination with youth's lack of financial management skills and an understanding which deters them from using formal saving products.

\section{References:}

1. Adomako, S. \& Albert, D. (2014). Financial Literacy and Firm performance: The moderating role of financial capital availability and resource flexibility.

2. Afon, A. (2012). "A survey of operational characteristics, socioeconomic and health effects of scavenging activity in Lagos, Nigeria", Waste Management and Research, 30(7).

3. Africa Waste Management Outlook - Summary for Decision-makers; United Nations Environment Programme UNEP (2011).

4. Agwu, M. O. (2014). Issues, challenges and prospects of Small and Medium Scale Enterprises (SMEs) in Port-Harcourt City, Nigeria. European Journal of Sustainable Development, 3:101-114.

5. Becker, G. S. (1964). Human capital. New York National Bureau of Economic Research 
6. Boateng, G.O., Boateng, A.A. \& Bampoe, H.S. (2014). Barriers to youth entrepreneurship in ana: A case study of Komenda-EdinaEguafo-Abirem (KEEA) in the central region of Ghana. Global Conference on Business and Finance proceedings, 9: 460-471.

7. Creswell, J. W. (2012). Qualitative inquiry \& research design: Choosing among five approaches (4th ed.). Thousand Oaks, CA: Sage.

8. Frumkin (2002). Strategic Positioning and the Financing of Nonprofit Organizations266-275

9. Georgieva, S. \& Allan, G. (2008). Best Practices in Project Management Through a Grounded Theory Lens. Electronic Journal of Business Research Methods, 6(1), 43-52.

10. Gratton. L. \& Ghoshal, S. (2003). Managing personal human capital: New ethos for Volunteer Employee; European Management Journal, vol. 21, issue 1, 1-10

11. Halimu, S. (2017). Youth unemployment in Kenya: towards an exploratory employment and wealth creation framework

12. Hewlett, R. (2002). Integrating human capital concepts in productivity and growth topics.

13. Kajamaa, A. (2011). Expansion learning between the works of evaluation and frontline work Article.

14. Kenya Economic Survey (2015). Kenya Bureau of statistics 2015 Edition; GOK

15. Kenya Youth Survey Report (2016). Youth Enterprise Development Fund: Status Report, Nairobi: Ministry of Youth Affairs.

16. Lincoln, Y. S. \& Guba, E. G. (1985). Naturalistic Inquiry. Newbury Park, CA: Sage Publications

17. Maruping, L. M. (2002). Human capital and firm performance: Understanding the impact of employee turnover on competitive advantage. Proceedings of the Academy of Management Conference, Denver

18. Nerdrum, L. \& Erikson, T. (2001). Intellectual capital: A human capital perspective. Journal of Intellectual Capital, 2: 127-135.

19. Quinn, P. (2008). Utilization-Focused Evaluation, 4th edition. Thousand Oaks, Ca: Sage Publications.

20. Rastogi, P. N. (2000). Sustaining enterprise competitiveness is human capital the answer? Human Systems Management, 19:193-203

21. Rebecca, S. (2016). Environmental citizenship: What can political theory contribute to environmental education practice: Article DOI: 10.1080/00958964.2015.1092417

22. Vroom, V.H. (1964). Work and Motivation, New York: Wiley. 
23. Wehmeyer, M. L. (2001). Self-determination and transition. In P. Wehman (Ed.). Life beyond the classroom: Transition strategies for young people with disabilities (3rd ed, pp. 35-60). Baltimore: Brookes

24. Wright, P. M. \& McMahan, G. C. (1992). Theoretical perspectives for human resource.

25. Youth Enterprise Development Fund-YEDF (2016). Report: http://www.youthfund.go.ke/ 